\title{
Antibiotic sensitivity testing: a survey undertaken in September 1970 in the United Kingdom
}

\author{
A. R. CASTle AND J. Elstub \\ From Oxoid Limited, Southwark Bridge Road, London
}

\section{Purpose of Survey}

A national survey was carried out in the United Kingdom in 1965 in order to identify the range of antibiotics and chemotherapeutic substances used in hospital laboratories for establishing the sensitivity of microorganisms from urinary infections, staphylococcal infections, and other infections. The results of this survey (which were published in booklet form by Oxoid Limited) revealed that whilst antibiotics were equally favoured in laboratories of all hospitals, large differences were evident in the choice of many other drugs.

A further survey was undertaken in September 1970 in order to identify any major changes in the choice of drugs for sensitivity testing since the last survey and also to obtain details of techniques currently employed. The results confirm some changes in the choice of drug and show very wide differences in technique.

A questionnaire was sent to most of the hospitals in the United Kingdom having laboratory facilities with an invitation to participate in the survey. In order to see if there were any major differences in the choice of drugs with hospitals of different size and status, they were divided into three groups as follows: teaching hospitals, large non-teaching hospitals, and other hospitals.

Teaching hospitals are those classified as such in the 1970 Hospital Year Book. Large non-teaching hospitals are those where the number of beds exceeds 500 .

\section{Response Rate}

A small number of laboratories did not complete the questionnaire because they omitted to answer one or more of the questions. It is for this reason that the figures in some of the tables and also in some sections of the text do not total 330-the number of hospitals responding. The response rate is shown in Table $\mathrm{I}$.

Recoived for publication 14 September_ 1971.

\begin{tabular}{llll}
\hline Hospital & $\begin{array}{l}\text { Total No. } \\
\text { of Hospitals }\end{array}$ & $\begin{array}{l}\text { No.of } \\
\text { Hospitals } \\
\text { Responding }\end{array}$ & $\begin{array}{l}\text { Percentage } \\
\text { Response Rate }\end{array}$ \\
\hline All & 645 & 330 & 51 \\
Teaching & 64 & 35 & 55 \\
Large non-teaching & 194 & 116 & 60 \\
Other & 387 & 179 & 45 \\
\hline
\end{tabular}

Table I Response rate

There were not many significant differences between practices in these three groups, and in the absence of such differences, results are given only for all hospitals.

\section{Techniques and Test Materials}

It has often been stated that the validity of results in a sensitivity test is dependent on a number of factors, such as the type of growth medium, the type of inoculum, method of spreading the inoculum, drug content of discs, use of controls, and the interpretation of results. In this survey, each of these factors was studied in order to ascertain the extent of their acceptance in the performance of sensitivity tests.

\section{SENSITIVITY TEST MEDIUM}

It is clear from Table II that there are differences of opinion among laboratories as to (1) the need to employ media specially formulated for sensitivity testing; (2) the need to employ some form of blood enrichment in the medium; (3) the best type of enrichment; and (4) the need to use plates containing a standard depth of medium.

Two hundred and sixty-two (79\%) of all hospitals employ a special medium for sensitivity testing. Of these, $89 \%$ use diagnostic sensitivity test agar, and $3 \%$ indicated a preference for salt agar when testing the sensitivity of staphylococci to methicillin.

One third approximately of all hospitals use media enriched with whole blood only, another third use media enriched with lysed blood only, and a quarter consider enrichment to be unnecessary. A small 


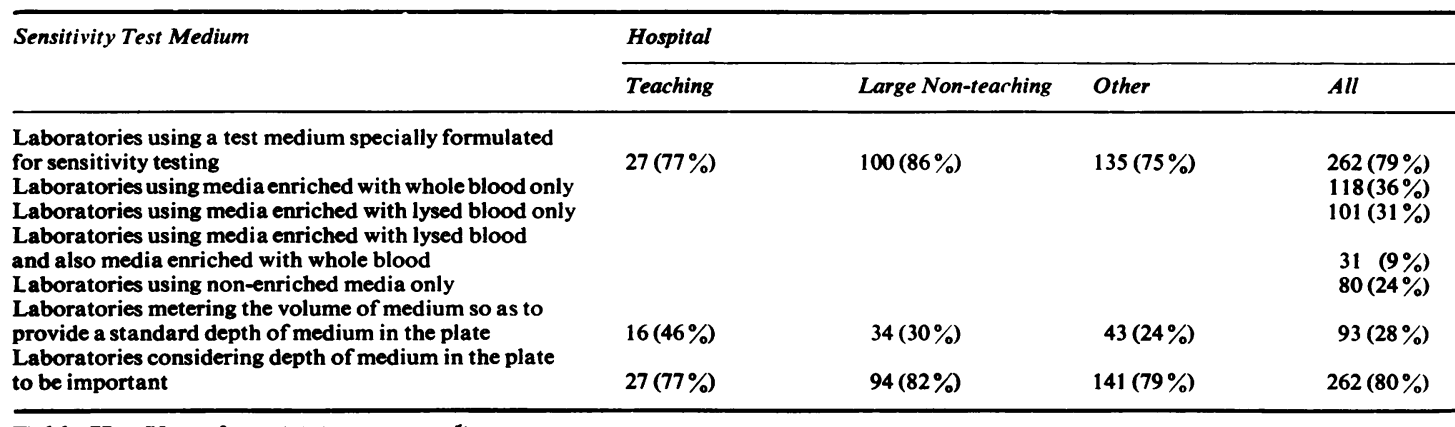

Table II Use of sensitivity test media

number of the hospitals using enriched media stated that non-enriched plates were employed when blood was considered to be unnecessary for growth of the test organism. There is no significant difference between the three 'groups' of hospitals in the use/choice of enrichment for the sensitivity test medium.

Of the 31 hospitals $(9 \%)$ which use media with lysed blood and also media with whole blood, many stated that the former are employed when testing for sensitivity to sulphonamides. One laboratory uses a medium containing both whole and lysed blood with a view to demonstrating haemolysis, and also to provide more clear-cut results when testing for sensitivity to sulphonamides.

It is interesting to note from Table II that 262 $(80 \%)$ of all hospitals consider the depth of the medium in the plate to be important, whereas only $67(28 \%)$ actually meter the volume so as to provide a standard depth. It should, however, be pointed out that some laboratories, although not metering the volume, attempt to achieve a standard depth when pouring the plates.

Four hospitals stated that depth of medium was unimportant if 'within reasonable limits', and another felt that provided it is enough to support good growth (3-4 $\mathrm{mm}$ ) and that each disc is controlled, depth of medium is unimportant.

\section{Inoculum}

\section{CHOICE OF INOCULUM}

Tests employing pure cultures were done by 176 $(53 \%)$ of all hospitals: $55(17 \%)$ prefer the direct plating method in which the specimen is used as the inoculum, while $98(30 \%)$ use either direct plating or a subculture according to the nature of the specimen.

In order to clarify the reasons for the above mentioned preferences, the authors telephoned a selection of hospitals and found the following:
1 Those laboratories which normally employ only $-y$ direct plating of the specimen do so in the belief $\omega$ that the speedy result so obtained is of paramount ? importance.

2 In the laboratories where only subcultures are used, it was held either that it was essential to use pure cultures of the test organism, or that the primary $\frac{1}{3}$ plating method does not permit control of the size $\stackrel{\Phi}{-}$ of the inoculum, or both.

3 Laboratories using both direct plating and $\vec{\varphi}$ subcultures have indicated a variety of approaches.some of which are: direct plating of urines and subcultures for other specimens; direct plating of urines when microscopy of specimen shows evidence of infections; and direct plating of all specimens except urines.

All of the laboratories with which a personal $\vec{F}$ approach was made concerning the use of direct 3 plating stated that subcultures were undertaken whenever the result with primary plates was in? doubt.

\section{SIZE OF THE INOCULUM}

The importance of controlling the size of the inoculum has been stressed by many workers. Nevertheless, $40 \%$ of teaching hospitals, $27 \%$ of large nonteaching hospitals, and $38 \%$ of other hospitals replied 을 to the questionnaire that they did not attempt to $\frac{I}{O}$ control the size of the inoculum.

SPREADING THE INOCULUM

The survey confirms that a wide variety of methods (singly and in combination) are used for spreading $\omega$ the inoculum on the plate. It will be seen frome Table III that more than one method of spreading is used by $21 \%$ of all laboratories. Personal com- $\mathbb{\Phi}$ munication with a random selection of these labora-? tories confirmed that their choice of method is $\frac{T}{C}$ determined by the nature of the specimen. In general, $\stackrel{\mathrm{D}}{\mathbb{D}}$ the swab is used when the specimen arrives on a swab $\frac{\rho}{\Phi}$ and a loop when the specimen is urine or pus. 


\begin{tabular}{|c|c|c|c|c|}
\hline \multirow[t]{2}{*}{ Means of Spreading } & \multicolumn{4}{|l|}{ Hospital } \\
\hline & Teaching & Large Non-teaching & Other & All \\
\hline $\begin{array}{l}\text { Loop only } \\
\text { Glass rod only } \\
\text { Swab only } \\
\text { Flooding only } \\
\text { Loop and swab } \\
\text { Loop and flooding }\end{array}$ & $\begin{array}{c}14(40 \%) \\
2(6 \%) \\
4(11 \%) \\
7(20 \%) \\
4(11 \%) \\
-\end{array}$ & $\begin{array}{c}48(42 \%) \\
5(4 \%) \\
21(18 \%) \\
17(15 \%) \\
8(7 \%) \\
9(8 \%)\end{array}$ & $\begin{array}{c}87(50 \%) \\
5(2 \%) \\
21(12 \%) \\
27(16 \%) \\
16(9 \%) \\
10(6 \%)\end{array}$ & $\begin{array}{l}149(46 \%) \\
11(3 \%) \\
46(14 \%) \\
51(16 \%) \\
28(9 \%) \\
19(6 \%)\end{array}$ \\
\hline
\end{tabular}

Table III Spreading the inoculum ${ }^{1}$

'In addition, six laboratories used both swab and flooding, three both loop and rod, one rod and swab, and 10 used other combinations including three which make a poured plate by mixing the inoculum with molten agar.

It is interesting to note that $46 \%$ of all laboratories favour 'loop only' as the means of spreading the plate.

\section{RESULTING GROWTH}

The survey revealed little evidence of any correlation between the type of inoculum, method of spreading, and the resulting growth. For example, major differences in growth density have been identified between laboratories which appear to be using identical methods for inoculating and spreading the plate. Fifty-nine percent of all hospitals usually obtain a dense but not confluent growth, $27 \%$ usually a confluent growth, $8 \%$ usually a variation in growth density, and $6 \%$ well separated colonies. Table IV shows the range of growth densities obtained in the various hospital groups.

\begin{tabular}{|c|c|c|c|c|}
\hline \multirow[t]{2}{*}{ Resulting Growth } & \multicolumn{4}{|l|}{ Hospital } \\
\hline & Teaching & $\begin{array}{l}\text { Large } \\
\text { Non- } \\
\text { teaching }\end{array}$ & Other & All \\
\hline \multirow{3}{*}{$\begin{array}{l}\text { Confluent ( } a \text { ) } \\
\text { Dense but not } \\
\text { confluent }(b) \\
\text { Well separated } \\
\text { colosies }(c)\end{array}$} & $17(48 \%)$ & $20(17 \%)$ & $53(30 \%)$ & $90(27 \%)$ \\
\hline & $16(46 \%)$ & $81(70 \%)$ & $98(55 \%)$ & $195(59 \%)$ \\
\hline & - & $5(4 \%)$ & $14(8 \%)$ & $19(6 \%)$ \\
\hline
\end{tabular}

\section{Table IV Resulting growth}

In addition, 12 laboratories described their growth as ranging between $(b)$ and $(c)$ and eight as either $(a)$ or $(b)$ and four as ranging between $(a)$ and $(c)$.

\section{Controls}

The survey revealed that $151(46 \%)$ of all hospitals control their tests with one or more standard organisms. Of these, $58(32 \%)$ stated that a control is provided for each test. Of the 151 laboratories using controls, $63 \%$ employ a standard strain of Staph. aureus (Oxford) or Ps. aeruginosa or E. coli, depending on the type of test organism or source of specimen. Thirty-seven per cent use a Staph. aureus (Oxford) only.
The value of the control procedure operated by some laboratories is somewhat questionable. In some departments, for example, it appears to be the practice to put up a control plate with each new batch of discs only, whereas others check each new batch of medium only. There are examples of controls consisting of an occasional testing of a Staph. aureus (Oxford).

\section{Disc Content}

Table $\mathrm{V}$ shows large differences in choice of disc content with eight antibiotics in 'front line' testing. Similar differences occur with many other antibiotics. (A table giving details of the entire range of drug levels used for both 'first' and 'second' line testing is available on application to the authors.)

The survey showed that the drugs which have a high ranking in 'frequency of use' are very often associated with a wider range of disc levels. In the case of routine 'front line' testing of staphylococci with penicillin, nine different drug levels are used in the range 0.5 units to 15 units. With tetracycline, eight different levels are used in the range $5 \mu \mathrm{g}$ to $125 \mu \mathrm{g}$. It is probable that the exceptionally high disc levels, such as tetracycline at $200 \mu \mathrm{g}$, are used only when testing the sensitivity of organisms from superficial infections to which the antibiotic is to be applied locally.

In $255(78 \%)$ of laboratories in all hospitals it is the practice to use a higher drug content in discs for testing organisms from urinary infections than in discs for staphylococcal infections.

There are no internationally agreed levels of antibiotics in sensitivity testing at the present time. When asked if they felt international standards were desirable, 288 hospitals replied Yes and 30 replied No.

\section{Range of Drugs}

A very wide range of antibiotics is used in both 'front-line' and 'second-line' testing procedures for 


\begin{tabular}{|c|c|c|c|}
\hline Antiobiotic & $\begin{array}{l}\text { First-line Testing } \\
\text { Urinary Infections }\end{array}$ & Staphylococcal Infections & Other Infections \\
\hline Ampicillin & $\begin{array}{l}\text { Six different disc drug contents used } \\
\text { Range }=2-50 \mu \mathrm{g} \\
\text { Dominant content } 25 \mu \mathrm{g}\end{array}$ & $\begin{array}{l}\text { Six different disc drug contents used } \\
\text { Range }=1 \cdot 5-25 \mu \mathrm{g} \\
\text { Dominant content } 2 \mu \mathrm{g}\end{array}$ & $\begin{array}{l}\text { Eight different disc drug contents used } \\
\text { Range }=1 \cdot 5-200 \mu \mathrm{g} \\
\text { Dominant content } 2 \mu \mathrm{g}\end{array}$ \\
\hline Cephaloridine & $\begin{array}{l}\text { Four different disc drug contents used } \\
\text { Range }=5-25 \mu \mathrm{g} \\
\text { Dominant content } 25 \mu \mathrm{g}\end{array}$ & $\begin{array}{l}\text { Five different disc drug contents used } \\
\text { Range }=5-25 \mu \mathrm{g} \\
\text { Dominant content } 25 \mu \mathrm{g}\end{array}$ & $\begin{array}{l}\text { Five different disc drug contents used } \\
\text { Range }=5-25 \mu \mathrm{g} \\
\text { Dominant content } 5 \mu \mathrm{g}\end{array}$ \\
\hline Erythromycin & $\begin{array}{l}\text { Four different disc drug contents used } \\
\text { Range }=5-50 \mu \mathrm{g} \\
\text { Dominant content } 10 \mu \mathrm{g}\end{array}$ & $\begin{array}{l}\text { Six different disc drug contents used } \\
\text { Range }=2-50 \mu \mathrm{g} \\
\text { Dominant content } 10 \mu \mathrm{g}\end{array}$ & $\begin{array}{l}\text { Four different disc drug contents used } \\
\text { Range }=2-50 \mu \mathrm{g} \\
\text { Dominant content } 10 \mu \mathrm{g}\end{array}$ \\
\hline Kanamycin & $\begin{array}{l}\text { Four different disc drug contents used } \\
\text { Range }=5-30 \mu \mathrm{g} \\
\text { Dominant content } 30 \mu \mathrm{g}\end{array}$ & $\begin{array}{l}\text { Four different disc drug contents used } \\
\text { Range }=5-50 \mu \mathrm{g} \\
\text { Dominant content } 30 / 50 \mu \mathrm{g}\end{array}$ & $\begin{array}{l}\text { Four different disc drug contents used } \\
\text { Range }=5-50 \mu \mathrm{g} \\
\text { Dominant content } 30 \mu \mathrm{g}\end{array}$ \\
\hline Nalidixic acid & $\begin{array}{l}\text { Four different disc drug contents used } \\
\text { Range }=25-200 \mu \mathrm{g} \\
\text { Dominant content } 30 \mu \mathrm{g}\end{array}$ & $\begin{array}{l}\text { Three different disc drug contents used } \\
\text { Range }=2-50 \mu \mathrm{g} \\
\text { Dominant content } 30 \mu \mathrm{g}\end{array}$ & $\begin{array}{l}\text { Two different disc drug contents used } \\
\text { Range }=30-50 \mu \mathrm{g} \\
\text { Dominant content } 30 \mu \mathrm{g}\end{array}$ \\
\hline Nitrofurantoin & $\begin{array}{l}\text { Five different disc drug contents used } \\
\text { Range }=20-500 \mu \mathrm{g} \\
\text { Dominant content } 200 \mu \mathrm{g}\end{array}$ & $\begin{array}{l}\text { One disc drug content used } \\
200 \mu \mathrm{g}\end{array}$ & $\begin{array}{l}\text { One disc drug content used } \\
200 \mu \mathrm{g}\end{array}$ \\
\hline Penicillin & $\begin{array}{l}\text { Eight different disc drug contents used } \\
\text { Range }=1-20 \text { units } \\
\text { Dominant content } 1.5 \text { units }\end{array}$ & $\begin{array}{l}\text { Nine different disc drug contents used } \\
\text { Range }=0.5-15 \text { units } \\
\text { Dominant content } 1.5 \text { units }\end{array}$ & $\begin{array}{l}\text { Seven different disc drug contents used } \\
\text { Range }=0.5-5 \text { units } \\
\text { Dominant content } 1.5 \text { units }\end{array}$ \\
\hline Tetracycline & $\begin{array}{l}\text { Six different disc drug contents used } \\
\text { Range }=10-125 \mu \mathrm{g} \\
\text { Dominant content } 50 \mu \mathrm{g}\end{array}$ & $\begin{array}{l}\text { Eight different disc drug contents used } \\
\text { Range }=5-125 \mu \mathrm{g} \\
\text { Dominant content } 10 \mu \mathrm{g}\end{array}$ & $\begin{array}{l}\mathrm{d} \text { Nine different disc drug contents used } \\
\text { Range }=5-200 \mu \mathrm{g} \\
\text { Dominant content } 10 \mu \mathrm{g}\end{array}$ \\
\hline
\end{tabular}

organisms from urinary infections, staphylococcal infections, and other infections alike. Forty-three different drugs are used in 'first-line' testing of urinary infections and 42 in the case of staphylococcal infections. Some of them have a very high ranking by frequency of use, whereas others are employed by just a few laboratories. There are no significant differences in the choice of drugs between the three groups of hospitals. Tables VI, VII, and VIII cover urinary infections, staphylococcal in- fections, and other infections respectively. In thefirst column of each table antibiotics are ranked by응 frequency of use in routine 'first-line' testing by乏 all hospitals. The number in each column represents the number of laboratories using the antibiotic for each particular purpose, eg, in the case of urinary® infections (Table VI) ampicillin is used by $317 \vec{\Rightarrow}$ hospitals for 'first-line' testing. It will also be seen⿳亠口了 that nine hospitals use this antibiotic for 'second-? line' testing.

\begin{tabular}{|c|c|c|c|c|}
\hline $\operatorname{Ran}$ & $k$ Antibiotic & $\begin{array}{l}\text { First Line } \\
\text { Testing }\end{array}$ & $\begin{array}{l}\text { Second } \\
\text { Line } \\
\text { Testing }\end{array}$ & Comment \\
\hline 1 & Ampicillin (5) & 317 & 9 & \\
\hline 2 & Nitrofurantoin (1) & 295 & 11 & $\begin{array}{l}\text { Also six and one } \\
\text { tested furaltadone } \\
\text { or furazolidone }\end{array}$ \\
\hline 3 & Nalidixicacid (7) & 275 & 39 & \\
\hline 4 & Tetracyclines (2) & 271 & 26 & $\begin{array}{l}\text { Comprising tetra- } \\
\text { cycline } 248 \text { and } 25, \\
\text { oxytetracycline } 17 \\
\text { and } 0, \text { chlortetra- } \\
\text { cycline } 6 \text { and } 1\end{array}$ \\
\hline 5 & Sulphonamides (3) & 270 & 12 & \\
\hline 6 & Polymyxins (8) & 208 & 142 & $\begin{array}{l}\text { Comprising } \\
\text { colistin methane } \\
\text { sulphonate } 180 \\
\text { and } 103 \text {, poly- } \\
\text { myxin B } 13 \text { and } 36, \\
\text { thiosporin } 5 \text { and } 3\end{array}$ \\
\hline
\end{tabular}

\begin{tabular}{|c|c|c|c|c|}
\hline \multicolumn{2}{|c|}{ Rank Antibiotic } & \multirow{2}{*}{$\begin{array}{l}\text { First Line } \\
\text { Testing } \\
185\end{array}$} & \multirow{2}{*}{$\begin{array}{l}\text { Second } \\
\text { Line } \\
\text { Testing }\end{array}$} & \multirow{2}{*}{$\begin{array}{l}\text { Comment } \\
\text { Including } 19 \text { and } \\
12 \text { testing tri- } \\
\text { methoprim singly }\end{array}$} \\
\hline 7 & $\begin{array}{l}\text { Trimethoprim/ } \\
\text { sulphamethoxazole (-) }\end{array}$ & & & \\
\hline 8 & Streptomycin (4) & 131 & 31 & \\
\hline 9 & Cephaloridine (12) & 83 & 95 & \\
\hline 10 & Kanamycin (9) & 83 & 122 & \\
\hline 11 & Chloramphenicol (6) & 70 & 49 & \\
\hline 12 & Gentamicin (-) & 57 & 186 & \\
\hline 13 & Penicillin (10) & 30 & 9 & \\
\hline 14 & Carbenicillin (-) & 23 & 208 & \\
\hline 15 & Cephalexin (-) & 20 & 33 & \\
\hline 16 & Erythromycin (11) & 17 & 7 & \\
\hline 17 & Cloxacillin (15) & 11 & 11 & \\
\hline 18 & Novobiocin (13) & 7 & 8 & \\
\hline 19 & Framycetin (19) & 5 & 10 & \\
\hline 20 & Cephalothin (-) & 4 & 6 & \\
\hline 21 & Methicillin (20) & 3 & 8 & \\
\hline
\end{tabular}

Table VI Antibiotics ranked by frequency of use in all hospitals in urinary infections.

${ }^{1}$ The ranking in the 1965 survey is shown in brackets.

'The following agents were tested by fewer than three ( $1 \%$ laboratories in 'first-line testing'. Lincomycin, fusidic acid, nystatin, phene $\overline{\mathbb{D}}$ thicillin, rifamides, propicillin, methacycline, doxycycline, 'paromomycin, albamycin, clindamycin, mandelamine, dicloxacillin, olean domycin, ristoceti n, spiramycin, vancomycin, pristinamycin. 


\begin{tabular}{llll}
\hline Rank Antibiotic & $\begin{array}{l}\text { First Line } \\
\text { Testing }\end{array}$ & $\begin{array}{l}\text { Second } \\
\text { Line } \\
\text { Testing }\end{array}$ & Comment \\
\hline
\end{tabular}

\begin{tabular}{lllll}
\hline 1 & Penicillin (2) & 298 & 8 & \\
2 & Tetracycline (1) & 298 & 8 & Comprising tetra-
\end{tabular}

2 Tetracycline (1) $298 \quad 8 \quad$ Comprising tetracycline 275 and 6 , oxytetracycline 15 and 1 , chlortetra-

$\begin{aligned} 3 & \text { Erythromycin (3) } \\ 4 & \text { Ampicillin (7) } \\ 5 & \text { Cloxacillin (6) } \\ 6 & \text { Streptomycin (4) } \\ 7 & \text { Chloramphenicol (5) } \\ 8 & \text { Fusidicacid (11) } \\ 9 & \text { Cephaloridine (13) } \\ 10 & \text { Methicillin (10) } \\ 11 & \text { Lincomycin (14) } \\ 12 & \text { Sulphonamides (8) } \\ 13 & \text { Neomycin (12) } \\ 14 & \text { Trimethoprim/ } \\ & \text { sulphamethoxazole (-) } \\ 15 & \text { Novobiocin (9) } \\ 16 & \text { Gentamicin (-) } \\ 17 & \text { Polymyxins (17) }\end{aligned}$

$\begin{array}{rr}224 & 51 \\ 197 & 25 \\ 162 & 56 \\ 162 & 25 \\ 109 & 59 \\ 101 & 158 \\ 92 & 75 \\ 84 & 61 \\ 84 & 106 \\ & \\ 83 & 13 \\ 71 & 54 \\ & \\ 78 & 63 \\ & \\ 46 & 52 \\ 23 & 77 \\ 13 & 19\end{array}$

18 Kanamycin (16)

19 Cephalexin (-)

20 Nalidixicacid (27)

21 Framycetin (15)

22 Nitrofurantoin (20)

$\begin{array}{rr}12 & 37 \\ 11 & 31 \\ 10 & - \\ 8 & 23 \\ 8 & 2\end{array}$

Also 6 and 30 tested clindamycin

Including 7 and 11 testing trimethoprim singly

Comprising colistin methane sulphonate 9 and 14 , polymyxin B 3 and 3 , thiosporin 1 and 2

$$
\frac{3}{23}
$$$$
37
$$$$
2
$$

Also 3 and 3 tested furaltadone or furazolidone

Table VII Antibiotics ranked by frequency of use in all hospitals in staphylococcal infections ${ }^{1}$

'Some laboratories also tested the following: paromomycin, lymecycline, methacycline, spiramycin. doxycycline, propicillin, albamycin demethylchlortetracycline, clindamycin, oleandomycin, carbenicillin, cephalothin, phenethicillin, rifamides, nystatin, vancomycin, bacitracin. 'Ranking in the 1965 survey (Tables VII and VIII)

\section{Number of Drugs}

It will be seen from Table IX that the number of different drugs employed in 'first-line' testing by all hospitals varies between one and 17 . The majority use either six or eight, and it is felt that the choice of this number may stem from the fact that multitype discs which contain either six or eight drugs are used by $61 \%$ of all hospitals.

\section{Changes in Choice of Drug}

The survey revealed that 150 laboratories change their range of drugs every two years approximately, 130 every year approximately, and 20 every six months approximately. Eight laboratories stated that they 'review' rather than 'change' their range, and two stated that changes were made 'as and when new drugs become available'.

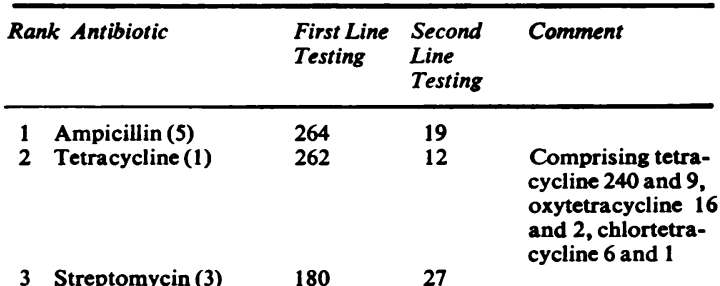

3 Streptomycin (3) $\quad 180$

4 Penicillin (2) 175

5 Chloramphenicol (4) 125

6 Sulphonamides (7) 126

7 Polymyxins (8) 120

27
8
83
18
152

Comprising colistin methane sulphonate 94 and 103 , polymyxin $B$ 24 and 43, thiosporin 2 and 6 Including 10 and 9

8 Trimethoprim/ sulphamethoxazole (-) 120

82 testing trimetho-

9 Cephaloridine (13)

10 Gentamicin (-)

11 Neomycin (9)

12 Cloxacillin (11)

13 Kanamycin (12)

14 Carbenicillin (-)

15 Framycetin (15)

16 Nalidixicacid (19)

17 Nystatin (14)

18 Novobiocin (10)

19 Cephalexin $(-)$

20 Fusidic acid (21)

21 Nitrofurantoin (16)

$\begin{array}{rr}99 & 73 \\ 83 & 138 \\ 80 & 69 \\ 73 & 17 \\ 65 & 99 \\ 47 & 151 \\ 24 & 39 \\ 21 & 7 \\ 21 & 34 \\ 18 & 15 \\ 17 & 37 \\ 17 & 33 \\ 17 & 17\end{array}$

prim singly

22 Lincomycin (24)

16

26

Also 4 and 4

tested furaltadone or furazolidone

Table VIII Antibiotics ranked by frequency of use in all hospitals in other infections ${ }^{1}$

1Some laboratories also tested the following: demethylchlortetracycline, oleandomycin, doxycycline, lymecycline, spiramycin, vancomycin, methacycline, propicillin, cycloserine, penotrane, albamycin, mandelamine, methicillin, bacitracin, paramomycin, cephalothin, clindamycin, rifamides, phenethicillin.

\begin{tabular}{|c|c|c|c|c|c|}
\hline \multicolumn{2}{|c|}{ Urinary Infections } & \multicolumn{2}{|c|}{ Staphylococcal Infections } & \multicolumn{2}{|c|}{ Other Infections } \\
\hline $\begin{array}{l}\text { No. of } \\
\text { Drugs }\end{array}$ & $\begin{array}{l}\text { Hospitals } \\
\text { Using this } \\
\text { Number }\end{array}$ & $\begin{array}{l}\text { No. of } \\
\text { Drugs }\end{array}$ & $\begin{array}{l}\text { Hospitals } \\
\text { Using this } \\
\text { Number }\end{array}$ & $\begin{array}{l}\text { No. of } \\
\text { Drugs }\end{array}$ & $\begin{array}{l}\text { Hospitals } \\
\text { Using this } \\
\text { Number }\end{array}$ \\
\hline 1 & - & 1 & 1 & 1 & 1 \\
\hline 2 & 1 & 2 & 1 & 2 & 4 \\
\hline 3 & 6 & 3 & 8 & 3 & 6 \\
\hline 4 & 23 & 4 & 26 & 4 & 25 \\
\hline 5 & 18 & 5 & 30 & 5 & 21 \\
\hline 6 & 48 & 6 & 57 & 6 & 59 \\
\hline 7 & 36 & 7 & 32 & 7 & 27 \\
\hline 8 & 129 & 8 & 111 & 8 & 94 \\
\hline 9 & 33 & 9 & 28 & 9 & 21 \\
\hline 10 & 12 & 10 & 10 & 10 & 10 \\
\hline 11 & 6 & 11 & 1 & 11 & 9 \\
\hline 12 & 1 & 12 & 3 & 12 & 8 \\
\hline 13 & 2 & 13 & 2 & 13 & 5 \\
\hline 14 & 3 & 14 & 1 & 14 & 2 \\
\hline 15 & 1 & 15 & 1 & 15 & 2 \\
\hline 16 & 1 & 16 & 2 & 16 & 2 \\
\hline 17 & 2 & 17 & - & 17 & 1 \\
\hline
\end{tabular}

Table IX Number of drugs used in first-line testing (all hospitals) 
The decision to change the range is made by the pathologist or bacteriologist in almost half of all hospitals. The survey shows that an antibiotics committee influences change of drug in $27 \%$ of all hospitals.

\section{Choice of Discs}

The various methods for sensitivity testing employed by different hospitals involves the use of different types of sensitivity discs. In all hospitals routine first-line testing, $62 \%$ use mainly multitipped devices, $20 \%$ use mainly single discs, and $15 \%$ use mainly ring devices with $1 \%$ using antibiotic tablets. Two per cent of all hospitals were found to be using the ditch plate method.

\section{Interpretation}

One hundred and twenty-five ( $38 \%$ ) of all hospitals grade their reports according to the size of zone of inhibition for any given antibiotic. Two gradings are employed by $62(50 \%)$ of these hospitals, three gradings by $62(50 \%)$, and four gradings by one laboratory. However, only $\mathbf{1 0 0}$ make any form of a comparison with a standard organism. Of these, 46 actually measure the zone (six by regression line), and 54 stated that a visual comparison (no measurement) is made with a standard organism.

It has often been stated that zones of inhibition measuring less than $2 \mathrm{~mm}$ radially from the edge of the disc should be ignored. The survey shows that $47(15 \%)$ of all hospitals answering this question do not ignore zones of less than $2 \mathrm{~mm}$.

\section{Reports}

Two hundred and eighty-four $(87 \%)$ of pathologists at all hospitals report to the clinician the results of all the antibiotics employed in routine first-line testing procedures. The figure for second-line 0 ) testing procedures is $235(72 \%)$.

It would appear that $71(22 \%)$ of pathologists at $\frac{C}{0}$ all hospitals limit their reports to the clinician to $\frac{\bar{c}}{2}$ those antibiotics they believe to be safest when an $\mathbb{D}$ organism is found to be sensitive to a number of antibiotics.

\section{Discussion}

The survey has revealed differences in choice of test $\frac{\hat{g}}{0}$ materials and techniques employed by hospital in laboratories in the United Kingdom. The methods $\stackrel{+}{6}$ used by most laboratories will no doubt enable the clinician to be provided with reliable information $\omega$ on the sensitivity of bacteria to antibiotics. There 의 are, however, laboratories which employ a method involving discs with a low drug content and a heavy inoculum. There are others which use the reverse, discs with a high drug content and a light inoculum. With some drugs, this difference may result in an organism being reported as resistant by one laboratory, fully sensitive by the other.

It may be felt that differences of this type, and others too, are sufficiently great to give cause for concern and that the adoption of a standard procedure for the performance of sensitivity tests is desirable in order to ensure that all hospitals employ a method which will give meaningful and repro- $\stackrel{\mathbb{D}}{\Omega}$ ducible results.

We should like to acknowledge the help and guidance received from Professor L. P. Garrod and Miss P. Waterworth, Department of Bacteriology, The? Royal Postgraduate Medical School, London, in the compilation of our questionnaire and also for their assistance in the preparation of this paper. 